Journal Club

Editor's Note: These short reviews of recent JNeurosci articles, written exclusively by students or postdoctoral fellows, summarize the important findings of the paper and provide additional insight and commentary. If the authors of the highlighted article have written a response to the Journal Club, the response can be found by viewing the Journal Club at www.jneurosci.org. For more information on the format, review process, and purpose of Journal Club articles, please see http://jneurosci.org/content/ preparing-manuscript\#journalclub.

\title{
Insights into the Contribution of Voltage-Gated Sodium Channel 1.7 to Paclitaxel-Induced Neuropathy
}

\author{
- $L$ Laura Bernal \\ Facultad de Medicina, Departamento de Biología de Sistemas (Fisiología), Universidad de Alcala, 28871 Alcalá de Henares, Spain \\ Review of Li et al.
}

Chemotherapy-induced peripheral neuropathy (CIPN) is a common side effect of antineoplastic treatments, such as paclitaxel (for review, see Mekhail and Markman, 2005). Paclitaxel exerts its effects by promoting tubulin assembly and preventing microtubule depolymerization, hence inhibiting cell division and causing cell death. Unfortunately, the effects are not restricted to tumor cells, and numbness, tingling, mechanical/thermal allodynia, and burning pain develop in $\sim 70 \%$ of treated patients (for review, see Seretny et al., 2014). Because no effective treatment prevents or relieves this kind of neuropathic pain, dose reduction or treatment cessation is required. Even after the discontinuation of therapy, however, symptoms can persist for months.

Animal models of paclitaxel-induced peripheral neuropathy show signs of mechanical allodynia and hyperalgesia, cold allodynia, and heat hyperalgesia that last up to $30 \mathrm{~d}$ (Polomano et al., 2001). Dissociated dorsal root ganglion (DRG) neurons from paclitaxel-treated rats show spontaneous activity that is not found in

Received March 16, 2018; revised May 18, 2018; accepted May 24, 2018.

L.B. is supported by a FPU (Formación del Profesorado Universitario) Scholarship (Ministerio de Educacion, Cultura y Deporte, Spain).

The authors declare no competing financial interests.

Correspondence should be addressed to Laura Bernal, Departimento

Biología de Sistemas, Facultad de Medicina, Campus Universitario, Universidad de Alcalá, 28871 Madrid, Spain. E-mail: laura.bernal@uah.es.

DOI:10.1523/JNEUROSCI.0692-18.2018

Copyright $\odot 2018$ the authors $\quad 0270-6474 / 18 / 386025-03 \$ 15.00 / 0$ control animals (Zhang and Dougherty, 2014; Li et al. 2017). In addition, DRG neurons in paclitaxel-treated rats have higher-than-normal levels of mRNA and protein for voltage-gated sodium channel $\mathrm{Na}_{\mathrm{v}} 1.7$ (Zhang and Dougherty, 2014; Xia et al., 2016). Notably, subcutaneous administration of low doses of tetrodotoxin (which blocks $\mathrm{Na}_{\mathrm{v}} 1.1-1.4, \mathrm{Na}_{\mathrm{v}} 1.6$, and $\left.\mathrm{Na}_{\mathrm{v}} 1.7\right)$ reduced the development of mechanical and cold allodynia in paclitaxeltreated mice (Nieto et al., 2008). Moreover, minocycline (a broad-spectrum tetracycline antibiotic) protects against neuropathy in taxol-treated rats (Boyette-Davis et al., 2011) and is thought to exert its effects through inhibition of sodium channels in primary afferents (Kim et al., 2011).

In a study recently published in The Journal of Neuroscience, Li et al. (2018) extended previous work by elucidating the specific types of DRG nociceptive neurons that show elevated expression of $\mathrm{Na}_{\mathrm{v}} 1.7$ after paclitaxel treatment. They also asked whether the function of these channels is also potentiated and assessed the contribution of the channels to mechanical hypersensitivity accompanying CIPN in rats. Finally, they obtained DRGs from patients with painful cancer-related neuropathy to further explore the role of $\mathrm{Na}_{\mathrm{v}} 1.7$ in the development of hyperexcitability and its possible role in neuropathy in humans.

To address these questions, they induced peripheral neuropathy in rats by in- jecting paclitaxel intraperitoneally on 4 nonconsecutive days. Consistent with previous work (Xia et al., 2016), paclitaxel treatment increased the level of $\mathrm{Na}_{\mathrm{v}} 1.7$ protein. This increase was found to be restricted to small- and medium-size nociceptive DRG neurons (mainly in peptidergic neurons, but also, to a lesser degree, in nonpeptidergic cells). The increased expression lasted for up to $14 \mathrm{~d}$ after the first injection, and thereafter started to decline despite persistent neuropathy. The authors also demonstrated that paclitaxel significantly increased the expression of $\mathrm{Na}_{\mathrm{v}} 1.7$ channel at the central terminals of nociceptive fibers in the spinal cord (Li et al., 2018).

Whole-cell recordings of small-size neurons (putative nociceptors) from DRG cultures from paclitaxel-treated rats revealed an increase in $\mathrm{Na}_{\mathrm{v}} 1.7$ current density. These currents also became activated at more hyperpolarized membrane potential in paclitaxel-treated neurons than in control neurons (Li et al., 2018). This increased current likely contributed to the development of spontaneous activity, which was found in 30\% of the recorded nociceptors. Indeed, the specific $\mathrm{Na}_{\mathrm{v}} 1.7$ blocker Pro-TxII abolished the current and the spontaneous activity.

It is likely that the development of spontaneous activity contributes to paclitaxel-induced neuropathic pain (Zhang and Dougherty, 2014; Li et al. 2017). Therefore, Li et al. (2018) explored 
whether the increase of the $\mathrm{Na}_{\mathrm{v}} 1.7$ channel is responsible for the mechanical hyperalgesia that developed after paclitaxel treatment. They found that intrathecal administration of Pro-TxII, either before paclitaxel treatment or after neuropathy was stablished, reduced mechanical hyperalgesia. This is in contrast with earlier studies that had failed to demonstrate attenuation of mechanical hyperalgesia in paclitaxel-treated rats after local DRG $\mathrm{Na}_{\mathrm{v}} 1.7$ blockade with a specific antibody (Xia et al., 2016). It may be that the blocking of peripheral channels is not sufficient to reduce hyperalgesia given that, as mentioned above, Li et al. (2018) detected increased expression of $\mathrm{Na}_{\mathrm{v}} 1.7$ in the spinal cord. But this would be inconsistent with a role of $\mathrm{Na}_{\mathrm{v}} 1.7$ channels in the cell body and the primary afferent.

Next, Li et al. (2018) investigated the mechanisms by which paclitaxel increases $\mathrm{Na}_{\mathrm{v}} 1.7$ expression. Previous work indicated that paclitaxel treatment increased the expression of toll-like receptor 4 (TLR4) and its downstream signaling protein myeloid differentiation primary response 88 (MyD88; Li et al., 2014). Therefore, Li et al. (2018) asked whether signaling via the TLR4-MyD88-MAPK pathway altered $\mathrm{Na}_{\mathrm{v}} 1.7$ expression. Indeed, LPS-RS (lipopolysaccharide from the photosynthetic bacterium Rhodobacter sphaeroides; a TLR4 antagonist) decreased $\mathrm{Na}_{\mathrm{v}} 1.7$ channel expression in DRGs from neuropathic rats. This is consistent with the attenuation of mechanical hypersensitivity observed in knock-out TLR4 mice after cisplatin treatment (Park et al., 2014). Previous studies also suggested that paclitaxel-induced activation of TLR4 leads to increased expression and release of TNF- $\alpha$ in satellite glial cells (Wu et al., 2015), and that high levels of TNF- $\alpha$ are associated with an increase in $\mathrm{Na}_{\mathrm{v}} 1.7$ channel in DRGs in rats with diabetic neuropathy (Huang et al., 2014). Thus, this might also contribute to $\mathrm{Na}_{\mathrm{v}} 1.7$ channel upregulation in paclitaxel-induced neuropathy.

Larger-than-normal $\mathrm{Na}_{\mathrm{v}} 1.7$ currents have also been described in patients treated with paclitaxel (Chang et al., 2018). Li et al. (2018) obtained DRGs from three patients with cancer-related neuropathies and confirmed by immunohistochemistry that $\mathrm{Na}_{\mathrm{v}} 1.7$ was present in half of the nociceptors. Remarkably, the increased expression of $\mathrm{Na}_{\mathrm{v}} 1.7$ was restricted to the DRGs that innervated painful dermatomes. Moreover, spontaneous activity, which was recorded only in neurons dissociated from DRGs that innervated painful dermatomes, was abolished by Pro-TxII. Essentially, the authors demonstrated that, like CIPN rats, nociceptors from patients with cancer-related neuropathies of different etiologies are sensitized and discharge at membrane potentials at which nociceptors are usually silent due to an overexpression of $\mathrm{Na}_{\mathrm{v}} 1.7$.

In summary, Li et al. (2018) showed increased expression and function of the $\mathrm{Na}_{\mathrm{v}} 1.7$ channel in rat and human DRG nociceptors, and that this increase in expression seems to contribute to neuropathic pain symptoms. The finding that blocking $\mathrm{Na}_{\mathrm{v}} 1.7$ reduces paclitaxel-induced neuropathy is somewhat surprising, given that $\mathrm{Na}_{\mathrm{v}} 1.7$ expression declines to baseline levels after $14 \mathrm{~d}$ even when neuropathy persists at least for 1 more week (Li et al. 2014). But spontaneously active nociceptors are considered an indicator of peripheral sensitization, which can potentiate central sensitization. This might explain how a transient upregulation of $\mathrm{Na}_{\mathrm{v}} 1.7$ contributes to longer-lasting sensitivity. On the other hand, these results may indicate that other mechanisms contribute to CIPN. One likely contributor is the T-type calcium channel, the specific blockade of which has also been shown to prevent mechanical hypersensitivity in paclitaxel-treated rats (Li et al., 2017). TRPV4 (transient receptor potential cation channel subfamily V member 4) channels may also play a role, given that antisense oligodeoxinucleotides against these channels abolished mechanical hyperalgesia induced by taxol (Alessandri-Haber et al., 2004). Thus, although the study by Li et al. (2018) advocates for $\mathrm{Na}_{\mathrm{v}} 1.7$ channels as a target to limit CIPN symptoms, the effectiveness of such treatments might be limited, because of the involvement of other ion channels. Furthermore, it is likely that these findings cannot be extrapolated to all neuropathies with different origins, given that, for example, mechanical hypersensitivity is independent of $\mathrm{Na}_{\mathrm{v}} 1.7$ in oxaliplatin-induced neuropathy (Minett et al. 2014).

Because genetic variants of $\mathrm{Na}_{\mathrm{v}} 1.7$ channels are associated with pain syndromes, several $\mathrm{Na}_{\mathrm{v}}$ blockers are being tested in clinical trials to treat chronic pain conditions (for review, see Emery et al., 2016). Unfortunately, these trials have shown little promise and demand further study. Not only synthetic drugs but also several natural toxins have considerable therapeutic effects by blocking $\mathrm{Na}_{\mathrm{v}}$ channels; however, their specificity and side effects limit their use. Nevertheless, the search for specific $\mathrm{Na}_{\mathrm{v}} 1.7$ antagonists opens up the possibility of finding more adequate treatments to limit the positive symptoms of patients with different neuropathies.

\section{References}

Alessandri-Haber N, Dina OA, Yeh JJ, Parada CA, Reichling DB, Levine JD (2004) Transient receptor potential vanilloid 4 is essential in chemotherapy-induced neuropathic pain in the rat. J Neurosci 24:4444-4452. CrossRef Medline

Boyette-Davis J, Xin W, Zhang H, Dougherty PM (2011) Intraepidermal nerve fiber loss corresponds to the development of taxol-induced hyperalgesia and can be prevented by treatment with minocycline. Pain 152:308-313. CrossRef Medline

Chang W, Berta T, Kim YH, Lee S, Lee SY, Ji RR (2018) Expression and role of voltage-gated sodium channels in human dorsal root ganglion neurons with special focus on Nav1.7, species differences, and regulation by paclitaxel. Neurosci Bull 34:4-12. CrossRef Medline

Emery EC, Luiz AP, Wood JN (2016) Nav1.7 and other voltage-gated sodium channels as drug targets for pain relief. Expert Opin Ther Targets 20:975-983. CrossRef Medline

Huang Y, Zang Y, Zhou L, Gui W, Liu X, Zhong Y (2014) The role of TNF-alpha/NF-kappa B pathway on the up-regulation of voltagegated sodium channel Nav1.7 in DRG neurons of rats with diabetic neuropathy. Neurochem Int 75: 112-119. CrossRef Medline

Kim TH, Kim HI, Kim J, Park M, Song JH (2011) Effects of minocycline on $\mathrm{Na}+$ currents in rat dorsal root ganglion neurons. Brain Res 1370: 34-42. CrossRef Medline

Li Y, Zhang H, Zhang H, Kosturakis AK, Jawad AB, Dougherty PM (2014) Toll-like receptor 4 signaling contributes to paclitaxel-induced peripheral neuropathy. J Pain 15:712-725. CrossRef Medline

Li Y, Tatsui CE, Rhines LD, North RY, Harrison DS, Cassidy RM, Johansson CA, Kosturakis AK, Edwards DD, Zhang H, Dougherty PM (2017) Dorsal root ganglion neurons become hyperecitable and increase expression of voltage-gated T-type calcium channels (cav3.2) in paclitaxel-induced peripheral neuropathy. Pain 158:417-429. CrossRef Medline

Li Y, North RY, Rhines LD, Tatsui CE, Rao G, Edwards DD, Cassidy RM, Harrison DS, Johansson CA, Zhang H, Dougherty PM (2018) DRG voltage-gated sodium channel 1.7 is upregulated in paclitaxel-induced neuropathy in rats and in humans with neuropathic pain. J Neurosci 38:1124-1136. CrossRef Medline

Mekhail M, Markman TM (2005) Paclitaxel in cancer therapy. Exp Opin Pharmacother 3:755-766. CrossRef Medline

Minett MS, Falk S, Santana-Varela S, Bogdanov YD, Nassar MA, Heegaard AM, Wood JN (2014) Pain without nociceptors? Nav1.7independent pain mechanisms. Cell Rep 6:301-312. CrossRef Medline

Nieto FR, Entrena JM, Cendán CM, Pozo ED, Vela JM, Baeyens JM (2008) Tetrodotoxin inhibits the development and expression of neuropathic pain induced by paclita- 
xel in mice. Pain 137:520-531. CrossRef Medline

Park HJ, Stokes JA, Corr M, Yaksh TL (2014) Toll-like receptor signaling regulates cisplatininduced mechanical allodynia in mice. Cancer Chemother Pharmacol 73:25-34. CrossRef Medline

Polomano RC, Mannes AJ, Clark US, Bennett GJ (2001) A painful peripheral neuropathy in the rat produced by the chemotherapeutic drug, paclitaxel. Pain 94:293-304. CrossRef Medline
Seretny M, Currie GL, Sena ES, Ramnarine S, Grant R, MacLeod MR, Colvin LA, Fallon M (2014) Incidence, prevalence, and predictors of chemotherapy-induced peripheral neuropathy: a systematic review and meta-analysis. Pain 155:2461-2470. CrossRef Medline

Wu Z, Wang S, Wu I, Mata M, Fink DJ (2015) Activation of TLR-4 to produce tumor necrosis factor- $\alpha$ in neuropathic pain caused by paclitaxel. Eur J Pain 19:889-898. CrossRef Medline
Xia Z, Xiao Y, Wu Y, Zhao B (2016) Sodium channel Nav1.7 expression is upregulated in the dorsal root ganglia in a rat model of paclitaxel-induced peripheral neuropathy. Springerplus 5:1738. CrossRef Medline

Zhang H, Dougherty PM (2014) Enhanced excitability of primary sensory neurons and altered gene expression of neuronal ion channels in dorsal root ganglion in paclitaxelinduced peripheral neuropathy. Anesthesiology 120:1463-1475. CrossRef Medline 